\title{
Pengaruh pendapatan asli desa, dana desa, dan alokasi dana perimbangan desa terhadap belanja desa
}

\author{
Khojanah Hasan ${ }^{1)}$, Maria Erlinda Tanesab ${ }^{2)}$ \\ Fakultas Ekonomi dan Bisnis, Universitas Widyagama Malang
}

\begin{abstract}
Abstrak
Tujuan, - Penelitian ini bertujuan untuk menguji dan menganalisis bagaimana pengaruh pendapatan asli desa, dana desa dan alokasi dana perimbangan desa terhadap belanja desa pada desa di Kabupaten Sidoarjo.

Desain/Methodologi/Pendekatan - Menggunakan 78 Desa di Kabupaten Sidoarjo. Pengujian analisis data menggunakan SPSS dalam menentukan adanya pengaruh ataupun tidak pengaruh dari variabel independen terhadap variabel dependen.

Temuan penelitian - Hasil penelitian menunjukkan bahwa Pendapatan Asli Desa, Dana Desa, dan Aloksi Dana Perimbangan Desa di Desa-desa Kabupaten Sidoarjo Provinsi Jawa Timur tahun 2017-2019 berpengaruh positif terhadap Belanja Desa.

Orisinalitas/nilai - Hasil penelitian ini memiliki nilai tambah yang berkontribusi dalam memperkuat konsep pengaruh pendapatan asli desa, dana desa, dan alokasi dana perimbangan desa terhadap belanja desa, baik secara parsial maupun simultan.
\end{abstract}

Kata kunci: Pendapatan asli desa, dana desa, alokasi dana perimbangan desa, belanja desa Jenis artikel: Artikel penelitian

\section{The effect of village original income, village funds, and allocation of village balance funds on village expenditures}

\begin{abstract}
Purpose, - This study aims to examine and analyze how the influence of village original income, village funds and the allocation of village balance funds on village expenditures in villages in Sidoarjo Regency.

Design/methodology/approach - Using 78 villages in Sidoarjo Regency. Testing data analysis using SPSS in determining whether or not there is an effect of the independent variable on the dependent variable.

Findings - The results showed that Village Original Income, Village Funds, and Allocation of Village Balance Funds in Sidoarjo Regency, East Java Province in 2017-2019 had a positive effect on Village Expenditures.

Originality/value - The results of this study have added value that contributes to strengthening the concept of the influence of village original income, village funds, and the allocation of village balance funds on village spending, either partially or simultaneously.
\end{abstract}

Keywords: Village original income, village fund, allocation of village balance funds, village expenditures Paper type: Research Paper 


\section{Pendahuluan}

Berdasarkan Undang-Undang Nomor 6 Tahun 2014 Tentang Desa, yang dimaksud dengan desa adalah kesatuan masyarakat hukum yang memiliki batas wilayah yang berwenang untuk mengatur dan mengurus urusan pemerintahan, kepentingan masyarakat setempat berdasarkan prakarsa masyarakat, hak asal usul, atau hak tradisional yang diakui dan dihormati dalam sistem pemerintahan Negara Kesatuan Republik Indonesia. Perangkat desa diangkat oleh kepala desa dan bertugas untuk membantu jalannya pemerintahan desa. Dimana hal ini menjadi fokus dari kebijakan pemerintah terkait pembangunan desa terutama dalam menjalankan otonomi daerah pemerintah mengeluarkan kebijakan.

Undang-Undang Nomor 25 tahun 1999 tentang pemerintah Perimbangan Keuangan antara pusat dan daerah Yang direvisi dengan Undang-Undang Nomor 33 tahun 2004. Dalam mewujudkan tata kelola keuangan pemerintah yang baik, pemerintah Indonesia melakukan reformasi di bidang keuangan negara dan daerah. Dalam mengelola keuangan desa juga perlu direncanakan dengan sebaik-baiknya, salah satunya dalam mengelola belanja desa yang diantaranya menyangkut dasar hukum, program atau kegiatan yang akan di laksanakan, jadwal pelaksanaan, siapa yang menjadi pelaku aktifitas dalam melaksanakan program, berapa besar anggaran yang dipergunakan, dan target apa yang harus dapat dicapai dengan pelaksanaan program/kegiatan yang dimaksud. Jumlah anggaran belanja pada APBDes maupun alokasi untuk setiap program/kegiatan merupakan jumlah tertinggi yang dapat dipergunakan dan harus dapat ditutup oleh pendapatan yang di perkirakan akan di terima oleh pemerintah desa.

Berdasarkan Permendagri Nomor 113 Tahun 2014 tentang Pengelolaan Keuangan Desa, Belanja Desa adalah semua pengeluaran dari rekening Desa yang merupakan kewajiban Desa dalam satu tahun anggaran yang tidak akan diperoleh pembayarannya kembali oleh Desa dan dipergunakan dalam rangka mendanai penyelenggaraan kewenangan Desa. Darwanto \& Yustikasari (2007) menyatakan bahwa pemanfaatan anggaran belanja seharusnya dialokasikan untuk hal-hal produktif, misalnya untuk pembangunan. Dalam hal ini sumbersumber dana yang digunakan untuk membiayai Belanja Desa diantaranya terdiri dari Pendapatan Asli Desa (PADesa), Dana Desa (DD), Alokasi Dana Perimbangan Desa (ADPD).

Pendapatan Asli Desa (PADes) bertujuan untuk melatih kemandirian setiap desa dalam mengelola semua potensi-potensi yang dimiliki sehingga perekonomiannya menjadi lebih baik. Belanja desa harus disesuaikan dengan besarnya pendapatan asli desa yang diperoleh. Semakin besar pendapatan asli desa yang diperoleh maka akan makin besar pula belanja desa yang bisa digunakan untuk pembangunan desa. Selain pendapatan Asli Desa, dana desa juga merupakan salah satu faktor yang dapat mempengaruhi belanja desa. Dalam Undang-undang Nomor 6 tahun 2014, menjelaskan bahwa desa akan mendapatkan dana desa yang diperoleh sebesar 10\% dari Anggaran Pendapatan dan Belanja Negara.

Kabupaten Sidoarjo sebagai salah satu kabupaten di provinsi jawa timur yang memiliki 18 kecamatan, 322 desa dan 31 keluruhan. Kabupaten sidoarjo memiliki potensi yang cukup besar dalam rangka pengenmbangan kemajuan desanya. Sesuai dengan perarturan Bupati Sidoarjo tahun 2019 Beberapa pendapatan asli desa meliputi: hasil usaha desa, hasil aset desa, hasil swadya, partisipasi masyarakat dan gotong royong dan lain-lain pendapatan asli desa yang sah. Dana desa yang berasal dari anggaran pendapatan dan belanja negara melalui anggaran pendapatan dan belanja daerah kabupaten/kota.

Adapun anggaran pendapatan dan Belanja Desa dari sampel 78 desa yang ada di kabupaten sidoarjo tahun 2017-2019 sebagaimana berikut: 
Tabel 1. Anggaran Pendapatan dan Belanja Desa dari sampel 78 desa yang ada di kabupaten sidoarjo tahun 2017-2019

\begin{tabular}{|l|l|l|l|l|l|}
\hline No & Tahun & PaDesa & Dana Desa & ADPD & Belanja Desa \\
\hline 1 & 2017 & 7.510 .837 .377 & 63.826 .657 .179 & 56.854 .046 .179 & 145.885 .212 .190 \\
\hline 2 & 2018 & 7.253 .836 .966 & 59.498 .984 .935 & 55.853 .933 .575 & 129.404 .112 .675 \\
\hline 3 & 2019 & 8.481 .037 .965 & 66.634 .321 .765 & 61.438 .314 .144 & 142.925 .959 .475 \\
\hline
\end{tabular}

Sumber data: Sipede Kemendesa

Dari data diatas dapat dilihat bahwa kontribusi dana desa dan alokasi dana perimbangan desa lebih besar dari apada kontribusi pendapatan asli desa. Fenomena masalah dalam penelitian ini yaitu jika pendapatan asli desa dan dana desa naik maka diikuti dengan naiknya belanja desa, sedangkan jika pendapatan asli desa dan dana desa turun maka akan diikuti pula dengan turunya belanja desa. Oleh karena itu perlu adanya pembuktian untuk mengetahui seberapa besar pengaruh dan dan hubungannya antara pendapatan asli desa dan dana desa dengan belanja desa.

Dalam penelitian sebelumnya yaitu Dasuki (2020) menyatakan PADesa dan Dana Desa berpengaruh signifikan terhadap Belanja Desa. Kemudian dalam penelitian dilakukan oleh Rokhmawan (2018) menyatakan bahwa PADesa tidak berpengaruh secara signifikan terhadap Belanja Desa di Bidang Pertanian tahun 2017 di Kabupaten Sragen, Bagi Hasil Pajak dan Retribusi tidak berpengaruh signifikan terhadap Belanja Desa bidang Pertanian tahun 2017 di Kabupaten sragen. Sedangkan penelitian yang dilakukan oleh Sulistiyoningtyas (2017) menyatakan bahwa Pendapatan asli desa dan Alokasi dana desa berpengaruh positif dan signifikan terhadap belanja desa di Kecamatan Baron, Pendapatan asli desa dan alokasi dana desa secara simultan berpengaruh signifikan terhadap belanja desa di kecmatan Baron.

Jadi dapat disimpulkan bahwa pernyataan yang dikeluarkan oleh peneliti berbeda-beda. Sesuai dengan hasil penelitian diatas membuat daya tarik peneliti untuk menganalisis bagaimana pengaruh pendapatan asli desa, dana desa dan alokasi dana perimbangan desa terhadap belanja desa pada desa di Kabupaten Sidoarjo. Oleh karena itu peneliti merumuskan Apakah ada pengaruh pendapatan asli desa (PADesa), Dana Desa, alokasi dana perimbangan desa (ADPD) terhadap belanja desa pada desa-desa dikabupaten Sidoarjo. Adapun tujuan penelitian ini, peniliti ingin mengetahui pengaruh pendapatan asli desa (PADesa), Dana Desa dan Alokasi Dana Perimbangan Desa terhadap belanja desa pada desa-desa dikabupaten Sidoarjo.

Menurut Permendagri Nomor 113 Tahun 2014 pendapatan desa meliputi semua penerimaan uang melalui rekening desa yang merupakan hak desa dalam satu tahun anggaran yang tidak perlu dibayar kembali oleh desa. Undang-Undang Nomor 6 Tahun 2014 menjelaskan pendapatan asli Desa adalah pendapatan yang berasal dari kewenangan Desa berdasarkan hak asal usul dan kewenangan skala lokal Desa. Sumber-sumber pendapatan asli desa menurut Undang Undang No. 6 tahun 2014 tentang Desa pasal 72 ayat 1 pendapatan asli desa bersumber dari hasil usaha, hasil aset, hasil swadya partisipasi, dan gotong royong dan lain- lain pendapatan desa.

Permendagri Nomor 113 Tahun 2014 dana desa adalah dana yang bersumber dari Anggaran Pendapatan dan Belanja Negara yang diperuntukkan bagi Desa yang ditransfer melalui Anggaran Pendapatan dan Belanja Daerah Kabupaten/Kota dan digunakan untuk membiayai penyelenggaraan pemerintahan, pelaksanaan pembangunan, pembinaan kemasyarakatan, dan pemberdayaan masyarakat. Menurut Undang-Undang Nomor 6 Tahun 2014 besaran alokasi anggaran yang peruntukannya langsung ke desa pun ditentukan $10 \%$ dari dan diluar dana transfer daerah (on top) secara bertahap, anggaran yang bersumber dari APBN dihitung berdasarkan jumlah desa dan dialokasikan dengan memperhatikan jumlah penduduk, angka kemiskinan, luas wilayah, dan tingkat kesulitan geografis guna 
meningkatkan kesejahteraan dan pemerataan pembangunan desa. Menurut Peraturan Pemerintah Nomor 22 Tahun 2015 tentang Perubahan Atas Peraturan Pemerintah Nomor 60 Tahun 2014 penyaluran dana desa dilakukan secara bertahap pada tahun anggaran berjalan dengan ketentuan: Tahap I pada bulan April sebesar 40\% (empat puluh per seratus), tahap II pada bulan Agustus sebesar 40\% (empat puluh per seratus) dan tahap III pada bulan Oktober sebesar $20 \%$ (dua puluh per seratus).

Adapun sumber pendapatan dana desa meliputi dana yang bersumber dari APBN, Bagian dari hasil PDRD Kabupaten/Kota, Alokasi dana desa dari kabupaten/kota, Bantuan keuangan dari APBD Provinsi dan APBD Kabupaten/Kota, Hibah dan sumbangan pihak ketiga, serta lain-lain pendapatan desa yang sah. Tujuan dan fungsi dana desa Mengacu kepada UU nomor 6 tahun 2014 tentang pemerintah desa, maka masyarakat secara umum diberikan kesempatan untuk berpartisipasi dengan tujuan meningkatkan kualitas hidup yang lebih baik. Dalam alur penyaluran dana desa yaitu dari APBN yang disalurkan dari RKUN ke RKUD oleh menteri keuangan selaku bendahara umum negara (BUN) melalui KPPN, sedangkan penyaluran dana desa dari RKUD ke RKD dilakukan oleh Bendahara Umum Daerah (BUD) yang menyalurkan ke APBD.

Dana Desa digunakan untuk membiayai penyelenggeraan pemerintah, pembangunan, pemberdayaan masyarakat dan kemasyarakatan. Dana Desa diprioritaskan untuk membiayai pembangunan dan pemberdayaan masyarakat. Penggunaan Dana Desa dan Rencana kerja pemerintah desa. Dalam Peraturan Menteri Desa, Pembangunan Daerah Tertinggal dan Transmigrasi Nomor 5 Tahun 2015 tentang Penetapan Prioritas Penggunaan Dana Desa Tahun 2015 menyebutkan bahwa prioritas penggunaan Dana Desa untuk pembangunan desa, dialokasikan untuk mencapai tujuan pembangunan desa yaitu meningkatkan kesejahteraan masyarakat desa dan kualitas hidup masyarakat serta penanggulangan kemiskinan.

Alokasi dana perimbangan desa adalah dana yang dialokasikan oleh pemerintah kabupaten untuk desa yang bersumber dari dana bagi hasil pajak daerah kepada desa, dana bagi hasil retribusi daerah kepada desa dan bagian dari alokasi dana desa yaitu dari dana perimbangan keuangan pusat dan daerah yang diterima oleh kabupaten setelah dikurangi dana alokasi khusus. Rincian Besaran Alokasi Dana Perimbangan Desa ditetapkan dengan Keputusan Bupati. Pencairan dana bagi hasil pajak daerah, dana bagi hasil retibusi daerah dan Alokasi Dana Desa dilakukan bertahap sesuai pembagian dua tahap dalam satu tahun anggaran.

Belanja desa meliputi semua pengeluaran dari rekening desa yang merupakan kewajiban desa dalam satu tahun anggaran yang tidak akan diperoleh pembayaran kembali oleh desa, belanja desa digunakan untuk mendanai penyelenggaraan kewenangan desa. Dalam hal ini sumber-sumber dana yang digunakan untuk membiayai Belanja Desa diantaranya terdiri dari Pendapatan Asli Desa (PADesa), Dana Desa (DD), Alokasi Dana Desa (ADD), bagi hasil pajak daerah dan retribusi daerah, bantuan keuangan dari APBD Provinsi dan bantuan keuangan dari APBD kabupaten/kota.

Ketentuan belanja desa sangat umum dan tidak ada batas maksimum maupun minimum untuk alokasi tertentu. Ketentuan seperti ini membawa konsekuensi positif dan negatif pada saat yang bersamaan. Konsekuensi positifnya desa mempunyai keleluasaan untuk merencanakan pengalokasian anggaran dalam rangka memenuhi kebutuhan pembangunan, sedangkan potensi konsekuensi negatif bisa terjadi dalam bentuk rendahnya kualitas belanja dari APBDes yang tercermin dalam postur APBDes yang lebih memenuhi kebutuhan elit desa (kepala desa, perangkat desa dan BPD) dibandingkan kebutuhan warga. Dengan model ketentuan seperti ini, maka alokasi belanja di APBDes tergantung pada dinamika politik anggaran desa (Irawan et al., 2018). Jenis jenis belanja desa sebagaimana tertuang dalam Permendagri pasal 19 tahun 2020, terbagi 4 jenis yaitu belanja pegawai, belanja barang dan jasa, belanja modal, dan belanja tak terduga. 
Gambar 1. Kerangka konseptual penelitian

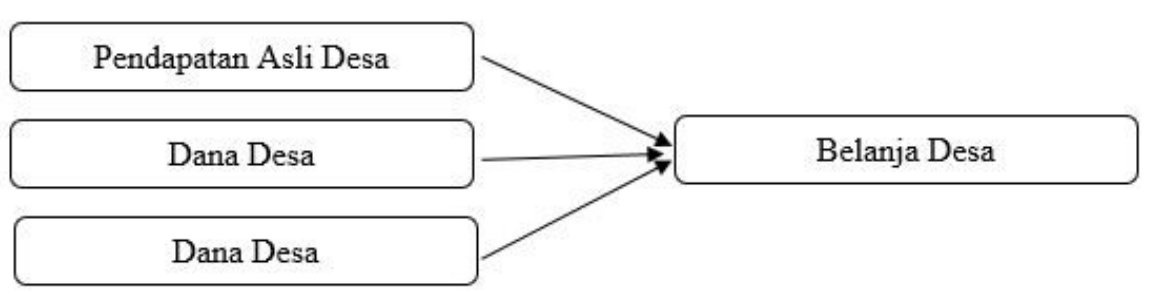

Dalam mewujudkan desa yang mandiri, desa dituntut untuk meningkatkan Pendapatan Asli Desanya sendiri tanpa ada campur tangan dari pemerintah pusat maupun pemerintah daerah. Pendapatan Asli Desa bertujuan untuk melatih kemandirian setiap desa dalam mengelola semua potensi-potensi yang dimiliki sehingga perekonomiannya menjadi lebih baik. Dengan didukung oleh sumber daya manusia dalam mengelola keuangan maka diharapkan dapat mengoptimalkan sumber-sumber yang ada didaerahnya demi memenuhi kebutuhan belanja desa dengan cara meningkatkan Pendapatan Asli Desa. Setiap desa memiliki sumber pendapatan desa yang berbeda-beda sesuai dengan besarnya potensi desa yang bersangkutan.

Begitu pula dengan belanja desa tentunya harus disesuaikan dengan besarnya pendapatan asli desa yang diperoleh. Semakin besar pendapatan asli desa yang diperoleh maka akan makin besar pula belanja desa yang bisa digunakan untuk pembangunan desa.

H1: Pendapatan Asli Desa berpengaruh positif terhadap Belanja Desa.

Pemerintah pusat memberikan dana desa secara umum dengan prioritas penggunaan dana desa ditujukan untuk membiayai pembangunan dan pemberdayaan masyarakat yang bertujuan untuk meningkatkan kesejahteraan masyarakat desa, peningkatan kualitas hidup manusia serta penanggulangan kemiskinan. Berkaitan dengan implementasi Undang-undang Nomor 6 tahun 2014 tentang desa yang menyebabkan pemerintah harus memaksimalkan penggunaan dana desa. Hal tersebut menunjukan bahwa dana desa yang ditransfer pemerintah pusat kepada pemerintah desa harus sepenuhnya digunakan untuk memenuhi kebutuhan belanja desa. Pelaksanaan kegiatan yang dibiayai dari dana desa diutamakan dilakukan secara swakelola dengan menggunakan sumber daya bahan baku lokal, dan diupayakan dengan lebih banyak menyerap tenaga kerja dari masyarakat desa setempat. Jadi dapat disimpulkan bahwa apa bila dana desa mengalami kenaikan maka nilai belanja desa juga akan naik.

H2 : Dana Desa berpengaruh Positif terhadap Belanja Desa.

Alokasi dana perimbangan desa adalah dana yang dialokasikan oleh pemerintah kabupaten untuk desa yang bersumber dari dana bagi hasil pajak daerah kepada desa, dana bagi hasil retribusi daerah kepada desa dan bagian dari alokasi dana desa yaitu dari dana perimbangan keuangan pusat dan daerah yang diterima oleh kabupaten setelah dikurangi dana alokasi khusus. Alokasi Dana Desa ini dapat mendukung pelaksanaan pembangunan partisipatif berbasis masyarakat dalam upaya pemberdayaan masyarakat pedesaan sekaligus memelihara kesinambungan pembangunan di tingkat desa. Dengan adanya Alokasi Dana Desa, desa memiliki kepastian pendanaan sehingga pembangunan dapat terus dilaksanakan tanpa harus terlalu lama menunggu datangnya dana bantuan dari pemerintah pusat. Irawan et al., (2018) menyatakan bahwa terdapat pengaruh positif antara Alokasi dana perimbangan desa dengan belanja desa. Jadi semakin tinggi nilai alokasi dana perimbangan desa maka nilai belanja desa juga akan naik.

H3: Alokasi Dana Perimbangan Desa berpengaruh positif Terhadap belanja desa.

Berdasarkan Undang- Undang Nomor 6 Tahun 2014 tentang Desa Pasal 72 disebutkan bahwa Pendapatan Desa bersumber dari Pendapatan Asli Desa yang berasal dari terdiri atas hasil usaha, hasil aset, swadaya dan partisipasi, gotong royong, dan lain-lain pendapatan asli desa, Dana Desa yang merupakan dana transfer dari pemerintah pusat dan Alokasi Dana Perimbangan Desa yang merupakan dana transfer dari pemerintah daerah. Ketiga dana tersebut saling berkaitan untuk memenuhi kebutuhan belanja desa dalam membangun sebuah desa yang maju. Jika pendapatan asli desa, dana desa dan alokasi dana perimbangan desa yang 
diperoleh setiap desa tinggi maka kebutuhan akan belanja desa nya pun akan tinggi juga. H4 : Pendapatan Asli Desa, Dana Desa dan Alokasi Dana Perimbangan Desa berpengaruh positif terhadap Belanja Desa

\section{Metode}

Objek penelitian ini dilakukan di kabupaten Sidoarjo, periode yang diambil dalam penelitian ini periode tahun 2017-2019. Sumber data yang digunakan dalam penelitian ini diperoleh dari Laporan Realisasi Anggaran Pendapatan dan Belanaja Desa yang diunduh dari situs web https://sid.kemendesa.go.id. Teknik pengumpulan data yang digunakan dalam penelitian ini adalah teknik dokumentasi dengan menggunakan data sekunder.

Populasi dari penelitian ini adalah pemerintahan desa kabupaten Sidoarjo yang terdiri dari 322 desa dan 31 kelurahan sehingga total populasinya adalah 353. Sampel adalah bagian dari populasi yang mempunyai karakteristik dianggap dapat mewakili keseluruhan populasi. Teknik sampling yang digunakan dalam penelitian ini mengunakan rumus Slovin dengan standar eror $10 \%$. Rumus Slovin adalah Suatu sistem matematis yang digunakan untuk menghitung jumlah dari sebuah populasi objek tertentu yang belum diketahui karakteristiknya secara pasti. Rumus slovin ini juga biasa digunakan jika populasi objek yang diteiliti sangat luas. Sehingga dengan hasil $\mathrm{n}=\mathrm{N} / 1+\mathrm{N} \cdot \mathrm{e}^{2}=353 / 1+353.0 .1^{2}=78$ desa yang dijadikan sampel. Maka jumlah sampel penelitian keseluruhan menjadi 3 x $78=234$ data.

Data Pendapatan Asli Desa, dana desa, dan Belanja Desa tahun anggaran tahun 2017-2019 diperoleh dari Sid-Kemendesa (https://sid.kemendesa.go.id). Adapun pengukuran dalam penelitian ini dilakukan dengan menggunakan analisis deskriptif dan regresi linier berganda dengan menggunakan SPSS.

\section{Hasil penelitian}

Dari hasil pengumpulan data sekunder mengenai Pendapatan Asli Desa, Dana Desa, Alokasi Dana Perimbangan Desa dan Belanja Desa pada Desa di Kabupaten Sidoarjo di Provinsi Jawa Timur Tahun 2017 - 2019. Maka nilai Minimum, Maksimum, Mean dan Standar deviasi dari variabel penelitian Pendapatan Asli Desa, Dana Desa, Alokasi Dana Perimbangan Desa dan Belanja Desa, adalah sebagai berikut:

Tabel 2. Deskriptif statistik

\begin{tabular}{|c|c|c|c|c|c|}
\hline & $\mathrm{N}$ & $\begin{array}{c}\text { Minimu } \\
\mathrm{m}\end{array}$ & $\begin{array}{c}\text { Maximu } \\
\mathrm{m}\end{array}$ & Mean & $\begin{array}{c}\text { Std. } \\
\text { Deviation }\end{array}$ \\
\hline PAD & 234 & 8 & 666 & 99.38 & 70.096 \\
$\mathrm{DD}$ & 234 & 670 & 997 & 811.77 & 72.937 \\
$\mathrm{ADPD}$ & 234 & 356 & 999 & 744.19 & 100.831 \\
$\mathrm{BD}$ & 234 & 82 & 261 & 178.71 & 21.631 \\
Valid N & 234 & & & & \\
(listwise) & & & & & \\
\hline
\end{tabular}

Sumber: data sekunder, diolah 2021

1. Pendapatan Asli Desa (PAD) memiliki nilai minimum sebesar 8, nilai Maximum sebesar 666 dan Mean sebesar 99,38 sedangkan Standar deviasi PAD sebesar 70.096

2. Dana Desa (DD) memiliki nilai minimum sebesar 670, nilai maximum sebesar 997 dan nilai mean sebesar 811.77 sedangkan standar deviasi DD sebesar 72.937

3. Alokasi Dana Perimbangan Desa (ADPD) memeiliki nilai minimum sebesar 356, nilai maximum sebesar 999 dan nilai mean sebesar 744.19 sedangkan standar deviasi ADPD sebesar 100.831 
4. Belanja Desa (BD) memiliki nilai minimum sebesar 82, nilai maximum sebesar 261 dan nilai mean sebesar 178.71 sedangkan standar deviasi BD sebesar 21.631

Salah satu cara termjudah untuk melihat normalitas residual adalah dengan melihat normal probability plot yang membandingkan distribusi kumulatif dari distribusi normal. Distribusi normal akan membentuk satu garis lurus diagonal, dan ploting data residul akan dibandingkan dengan garis diagonal. Jika distribusi data residual normal, maka garis yang menggambarkan data sesungguhnya akan mengikuti garis diagonal. Adapun hasil uji normalitas dengan menggonakan normal probability plot dapat dilihat sebagai berikut:

\section{Gambar 2. Uji Normalitas dengan Norma P-Plot}

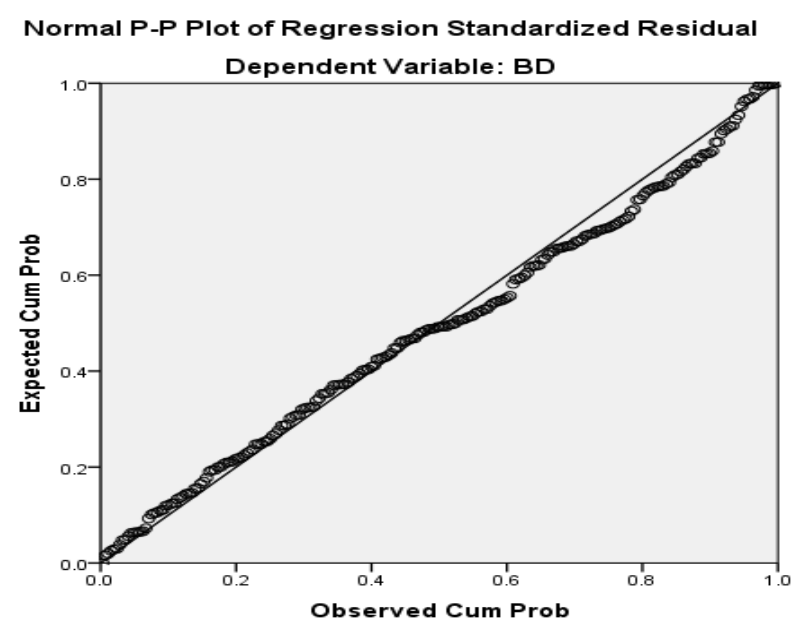

Sumber : data sekunder, diolah 2021

Pada grafik normal probability plot diatas terlihat bahwa titik-titik menyebar berhimpit di sekitar garis diagonal, serta penyebarannya mengikuti garis diagonal. Maka model regresi ini memenuhi asumsi normalitas.

Uji statistik lain yang dapat digunakan untuk menguji normalitas residual adalah uji statistik non-parametrikKolmogorov-Smirnov (K-S). Uji ini digunakan untuk menghasilkan angka yang lebih detail, apakah suatu persamaan regresi akan dipakai lolos normalitas apabila nilai signifikansi uji Kolmogorov-Smirnov lebih dari 0,05. Adapun uji normalitas dengan uji one sample kolmogorov-Smirnov adalah sebagai berikut:

Tabel 3. Hasil Uji Kolmogorov-Smirnov

\begin{tabular}{|cc|c|}
\hline & & Unstandardized Residual \\
\hline \multirow{2}{*}{ Normal Parameters $^{\mathrm{a}, \mathrm{b}}$} & $\mathrm{N}$ & 234 \\
& Mean & .0000000 \\
Most Extreme & Std. Deviation & 24.78789804 \\
Differences & Absolute & .059 \\
& Positive & .059 \\
& Negative & -.031 \\
& Test Statistic & .059 \\
\multicolumn{2}{|c|}{ Asymp. Sig. (2-tailed) } & $.047^{\mathrm{c}}$ \\
\hline
\end{tabular}

a. Test distribution is Normal.

b. Calculated from data.

c. Lilliefors Significance Correction.

Sumber: data sekunder, diolah 2021 
Hasil uji normalitas dapat dilihat pada tabel diatas, nilai Kolmogorov-Smirnov 0,059 dengan probabilitas signifikansi 0,47 lebih dari $\alpha=0,05$, berarti data terdistribusi secara normal, dan model regresi ini memenuhi uji normalitas.Dalam penelitian ini, menganalisis perubahan Pendapatan Asli Desa, Dana Desa, Alokasi Dana Perimbangan Desa dan Belanja Desa. Adapun hasil pengolahan data tersebut dan dapat dilihat pada tabel dibawah ini :

Tabel 4. Hasil Uji Regresi Linear Berganda

\begin{tabular}{|c|c|c|r|r|r|}
\hline & \multicolumn{2}{|c|}{$\begin{array}{c}\text { Unstandardized } \\
\text { Coefficients }\end{array}$} & $\begin{array}{c}\text { Std. } \\
\text { Coefficients }\end{array}$ & \multirow{2}{*}{} & \\
\cline { 2 - 4 } Model & \multicolumn{1}{|c|}{$\begin{array}{c}\text { Std. } \\
\text { Error }\end{array}$} & Beta & T & Sig. \\
\hline 1 (Constant) & 37.696 & 12.962 & & 2.908 & .004 \\
PAD & .045 & .017 & .143 & 2.693 & .008 \\
DD & .098 & .018 & .331 & 5.579 & .000 \\
ADPD & .076 & .013 & .356 & 5.934 & .000 \\
\hline
\end{tabular}

a. Dependent Variable: BD

Sumber : data sekunder, diolah 2021

Berdasarkan tabel diatas dapat diketahui model persamaan regresi linier berganda yaitu sebagai berikut : $\mathrm{Y}=\mathrm{a}+\mathrm{b} 1 \mathrm{X} 1+\mathrm{b} 2 \mathrm{X} 2+\mathrm{b} 3 \mathrm{X} 3$

$$
\mathrm{Y}=37.696+0.045 \mathrm{X} 1+0.098 \mathrm{X} 2+0.076 \mathrm{X} 3
$$

1. Berdasarkan hasil persamaan berikut, Konstanta dalam regresi sebesar 37.696 dan bertanda positif. Hal ini menunjukkan bahwa pendapatan asli desa, dana desa dan alokasi dana perimbangan desa memiliki nilai nol (0) maka belanja desa akan meningkat sebesar 238.554. artinya jika pendapatan asli desa,dana desa dan alokasi dana perimbangan desa maka belanja desa mengalami peningkatan.

2. Koefisien regresi Pendapatan Asli Desa (X1) sebesar 0.0045 dan bertanda positif. Artinya bahwa setiap kenaikan besaran 1 satuan pada variabel pendapatan asli desa maka akan meningkatkan Belanja Desa sebesar 0.045.

3. Koefisien regresi Dana Desa (X2) sebesar 0,098 dan bertanda positif. Artinya bahwa setiap kenaikan besaran 1 satuan pada variabel Dana Desa maka akan meningkatkan belanja desa sebesar sebesar 0,098.

4. Koefisien regresi Alokasi Dana Perimbangan Desa (X3) sebesar 0,076, dan bertanda positif. Artinya bahwa setiap kenaikan besaran 1 satuan pada variabel Alokasi Dana Perimbangan Desa maka akan meningkatkan belanja desa sebesar sebesar 0,076.

Selanjutnya yaitu melihat koefisien determinasi $\left(\mathrm{R}^{2}\right)$ guna mengukur seberapa jauh kemampuan model dalam menerangkan variabel dependen. Nilai $\mathrm{R}^{2}$ yang kecil berarti kemampuan independen dalam menjelaskan variabel dependen amat terbatas. Nilai yang mendekati satu berarti variabel independen memberikan hamper semua informasi yang dibutuhkan untuk memprediksikan variabel dependen. (Tabachnick, 1996). Koefisien Determinasi tampak pada gambar berikut:

Tabel 5. Hasil Uji Koefisien Determinasi $\left(\mathrm{R}^{2}\right)$

\begin{tabular}{|c|c|c|c|c|}
\hline Model & $\mathrm{R}$ & R Square & Adjusted R Square & Std. Error of the Estimate \\
\hline 1 & $.616^{\mathrm{a}}$ & .379 & .371 & 17.156 \\
\hline
\end{tabular}

a. Predictors: (Constant), ADPD, PAD, DD

b. Dependent Variable: BD

Sumber : data sekunder, diolah 2021 
Berdasarkan tabel 4.7 diatas dapat diketahui bahwa nilai Adjusted R Square sebesar 0,371 atau sebesar 37,1\%. Hasil ini menunjukkan bahwa belanja desa dipengaruhi sebesar 37,1\% oleh pendapatan asli desa, dana desa, dan alokasi dana perimbangan desa. Sedangkan $62,9 \%$ sisanya dipengaruhi oleh faktor lain selain tiga variabel independen dalam penelitian ini.

Berikutnya dilakukan Uji stastik F yang pada dasarnya untuk menunjukkan apakah semua varaibel independen yang dimasukan dalam model mempunyai pengaruh secara bersamasama terhadap variabel dependen Hipotesis nol yang hendak diuji adalah apakah semua parameter dalam model sama dengan nol.

Tabel 6. Hasil Uji F

\begin{tabular}{|cc|c|c|c|c|c|}
\hline & & & & & & \\
& & & & & & \\
& Model & Sum of Squares & Df & Mean Square & F & Sig. \\
\hline 1 & Regression & 41324.786 & 3 & 13774.929 & 46.802 & $.000^{\mathrm{b}}$ \\
& Residual & 67695.030 & 230 & 294.326 & & \\
& Total & 109019.816 & 233 & & & \\
\hline
\end{tabular}

Sumber : data sekunder, diolah 2021

Berdasarkan kolom sig. pada tabel 4.8 hasil uji $\mathrm{F}$ diatas, diperoleh nilai signifikansi 0,000 lebih kecil dari probabilitas 0,05. Dan nilai Fhitung $>$ Ftabel yaitu $46.802>2.643680$ maka Ho ditolak Ha diterima. Hal ini berarti pendapatan asli desa, dana desa dan alokasi dana perimbangan desa secara simultan berpengaruh terhadap belanja desa sehingga hipotesis keempat pada penelitian ini dapat dibuktikan kebenarannya.

Tabel 7. Hasil Uji Parsial

\begin{tabular}{|c|c|c|c|c|c|c|}
\hline & \multirow[b]{2}{*}{ Model } & \multicolumn{2}{|c|}{ Unstandardized Coefficients } & $\begin{array}{l}\text { Standardized } \\
\text { Coefficients }\end{array}$ & \multirow[b]{2}{*}{$\mathrm{T}$} & \multirow[b]{2}{*}{ Sig. } \\
\hline & & B & Std. Error & Beta & & \\
\hline \multirow[t]{4}{*}{1} & (Constant) & 37.696 & 12.962 & & 2.908 & .004 \\
\hline & PAD & .045 & .017 & .143 & 2.693 & .008 \\
\hline & DD & .098 & .018 & .331 & 5.579 & .000 \\
\hline & ADPD & .076 & .013 & .356 & 5.934 & .000 \\
\hline
\end{tabular}

a. Dependent Variable: BD

Sumber : data sekunder, diolah 2021

Hasil uji parsial adalah sebagai berikut :

1. Dari tabel diatas dapat disimpulkan bahwa nilai thitung pada pendapatan asli desa adalah sebesar 2.693 dengan nilai dan tingkat signifikan sebesar 0.008 . karena nilai thitung $>$ ttabel yaitu $2.693>1.970332$ dan nilai signifikansinya $0.008<0.05$ maka Ha diterima dan Ho ditolak. Dengan demikian hipotesis pertama yang menyatakan bahwa pendapatan asli desa berpengaruh positif secara signifikan terhadap belanja desa terbukti kebenarannya. Nilai t positif menunjukkan bahwa pendapatan asli desa mempunyai hubungan yang searah dengan belanja desa.

2. Dari tabel diatas dapat disimpulkan bahwa nilai thitung pada dana desa adalah sebesar 5.579 dengan nilai dan tingkat signifikan sebesar 0.000 . karena nilai thitung $>$ ttabel yaitu $5.579>1.970332$ dan nilai signifikansinya $0.000<0.05$ maka Ha diterima dan Ho ditolak. Dengan demikian hipotesis kedua yang menyatakan bahwa dana desa berpengaruh positif secara signifikan terhadap belanja desa terbukti kebenarannya. Nilai t positif menunjukkan 
bahwa Dana desa mempunyai hubungan yang searah dengan belanja desa.

3. Dari tabel diatas dapat disimpulkan bahwa nilai thitung pada Alokasi dana perimbangan desa adalah sebesar 5.934 dengan nilai dan tingkat signifikan sebesar 0.000. karena nilai thitung $>$ ttabel yaitu $5.934>1.970332$ dan nilai signifikansinya $0.000<0.05$ maka Ha diterima dan Ho ditolak. Dengan demikian hipotesis ketiga yang menyatakan bahwa Alokasi dana perimbangan desa berpengaruh positif secara signifikan terhadap belanja desa terbukti kebenarannya. Nilai t positif menunjukkan bahwa Alokasi dana perimbangan desa mempunyai hubungan yang searah dengan belanja desa.

\section{Pembahasan}

Berdasarkan hasil penelitian tentang pengaruh pendapatan asli desa, dana desa, dan dana aloksi perimbangan desa terhadap belanja desa pada Desa-desa di kabupaten Sidoarjo Provinsi Jawa Timur tahun 2017-2019 dilakukan pembahasan sebagai berikut:

1. Pengaruh pendapatan asli desa terhadap belanja desa

Variabel pendapatan asli desa berpengaruh signifikan terhadap belanja desa. Karena nilai thitung bertanda positif dan nilai thitung lebih besar dari ttabel yaitu $2.693>1.970332$ dan nilai sig. lebih kecil dari 0.05 yaitu $0.008<0.05$ berarti variabel pendapatan asli desa memiliki arah hubungan positif dengan belanja desa. Semakin tinggi nilai pendapatan asli desa maka belanja desa akan semakin tinggi. Sebaliknya, semakin rendah pendapatan asli desa maka belanja desa juga akan rendah.

Menurut Undang-Undang Nomor 6 Tahun 2014 Tentang Desa, pendapatan asli desa adalah pendapatan yang berasal dari kewenangan desa berdasarkan hak asal-usul dan kewenangan skala local desa. Pendapatan asli desa antara lain terdiri dari hasil usaha desa, hasil kekayaan desa, hasil swadaya dan partisipasi, hasil gotong royong, dan lain-lain pendapatan asli desa yang sah. Dana yang diperoleh dari pendapatan asli desa sebagian besar digunakan untuk kesejahteraan masyarakat dan pembangunan desa dalam skala kecil. Pendapatan asli desa yang diperoleh setiap desa di Indonesia masih sangat rendah. Hasil penelitian ini sesuai dengan teori tersebut yang menunjukan bahwa pendapatan asli desa berpengaruh terhadap belanja desa. Pendapatan asli desa masih tergolong rendah, hal ini dikarenakan masih rendahnya kemandirian keuangan desa karena pendapatan asli desa yang diperoleh setiap desa di kabupaten Sidoarjo masih sedikit. Oleh sebab itu karena pendapatan asli desa yang diperoleh masih sedikit desa dituntut untuk meningkatkan pendapatan asli desanya sehingga perekonomian desa menjadi lebih baik. Selain itu juga dengan didukung oleh sumber daya manusia yang baik dalam mengelola keuangan maka akan dapat mengoptimalkan sumber- sumber yang ada didaerahnya untuk memenuhi kebutuhan belanja desa salah satunya dengan cara meningkatkan pendapatan asli desa.

Dapat disimpulkan bahwa pendapatan asli desa berpengaruh signifikan positif terhadap belanja desa pada Desa-desa dikabupaten Sidoarjo tahun 2017-2019. Hasil penelitian ini juga sesuai dengan penelitian yang dilakukan oleh Mulyani (2020) dan Dasuki (2020) yang menyatakan bahwa pendapatan asli desa berpengaruh signifikan terhadap belanja desa. Sehingga hipotesis pertama yang menyatakan bahwa pendapatan asli desa berpengaruh signifikan positif terhadap belanja desa dapat dibuktikan kebenarannya.

2. Pengaruh Dana desa terhadap Belanja desa

Variabel dana desa berpengaruh signifikan terhadap belanja desa. Karena nilai thitung bertanda positif dan nilai thitung lebih besar dari ttabel yaitu $5.579>1.970332$ dan nilai sig. lebih kecil dari 0.05 yaitu $0.000<0.05$ berarti variabel Dana desa memiliki arah hubungan positif dengan belanja desa. Semakin tinggi nilai dana desa maka belanja desa akan semakin tinggi. Sebaliknya, semakin rendah nilai Dana desa maka belanja desa juga akan rendah.

Menurut Permendagri Nomor 113 Tahun 2014 dana desa merupakan dana yang ditransfer oleh pemerintah pusat dari Anggaran Pendapatan dan Belanja Negara kepada 
pemerintah desa sebesar $10 \%$. Dana desa yang diterima oleh setiap desa berbeda-beda sesuai dengan alokasi dasar dan alokasi formula masing-masing. Prioritas penggunaan dana desa untuk belanja desa ditujukan pada bidang pembangunan dan pemberdayaan masyarakat. Hasil penelitian ini sesuai dengan teori tersebut jadi dapat disimpulkan bahwa dana desa berpengaruh terhadap belanja desa. Artinya kebijakan pemerintah dalam memberikan dana transfer berupa dana desa yang diberikan kepada pemerintah desa telah berjalan dengan baik. Hasil penelitian ini juga sesuai dengan penelitian yang dilakukan oleh Mulyani (2020) dan Irawan et al., (2018) yang menyatakan bahwa dana desa berpengaruh signifikan terhadap belanja desa. Sehingga hipotesis kedua yang menyatakan bahwa dana desa berpengaruh terhadap belanja desa dapat dibuktikan kebenarannya.

3. Pengaruh Alokasi dana perimbangan desa terhadap belanja desa.

Variabel alokasi dana perimbangan desa berpengaruh signifikan terhadap belanja desa. Karena nilai thitung bertanda positif dan nilai thitung lebih besar dari ttabel yaitu $5.934>$ 1.970332 dan nilai sig. lebih kecil dari 0.05 . yaitu $0.000<0.05$ berarti variabel Alokasi dana perimbangan desa memiliki arah hubungan positif dengan belanja desa. Semakin tinggi nilai alokasi dana perimbangann desa maka belanja desa akan semakin tinggi. Sebaliknya, semakin rendah nilai alokasi dana perimbangan desa maka belanja desa juga akan rendah.

Secara teoritis Alokasi dana perimbangan desa adalah dana yang dialokasikan oleh pemerintah kabupaten untuk desa yang bersumber dari dana bagi hasil pajak daerah kepada desa, dana bagi hasil retribusi daerah kepada desa dan bagian dari alokasi dana desa yaitu dari dana perimbangan keuangan pusat dan daerah yang diterima oleh kabupaten setelah dikurangi dana alokasi khusus. Rincian Besaran Alokasi Dana Perimbangan Desa ditetapkan dengan Keputusan Bupati. Hasil penelitian ini sesuai dengan teori tersebut jadi dapat disimpulkan bahwa dana desa berpengaruh terhadap belanja desa. Hasil dari penelitian ini sesuai dengan teori tersebut yang menunjukan bahwa alokasi dana perimbangan desa berpengaruh terhadap belanja desa. Artinya Kebijakan pemerintah dalam memberikan dana transfer berupa alokasi dana perimbangan desa yang diberikan kepada pemerintah desa telah berjalan dengan baik. Hasil penelitian ini juga sesuai dengan penelitian yang di lakukan oleh Irawan et al., (2018) yang menyatakan bahwa alokasi dana perimbangan desa berpengaruh signifikan terhadap belanja desa.Sehingga dapat disimpulkan bahwa hipotesis ketiga yang menyatakan bahwa alokasi dana perimbangan desa berpengaruh terhadap belanja desa dapat dibuktikan kebenarannya.

4. Pengaruh Pendapatan asli desa, Dana desa, dan Alokasi dana perimbangan desa terhadap Belanja desa.

Variabel pendapatan asli desa, dana desa dan alokasi dana perimbangan desa seacara bersama-sama berpengaruh dan signifikan terhadap belanja desa. Hal ini dibuktikan dengan uji simultan Fhitung $>$ Ftabel yaitu $46.802>2.643680$ mempunyai hubungan yang searah dengan nilai sig. $0.000<0.05$. Hasil dari penelitian ini menunjukan bahwa belanja desa tergolong tinggi, hal ini dikarenakan pendapatan desa yang diperoleh oleh setiap desa tahun ketahun semakin meningkat sehingga mengakibatkan kebutuhan belanja desanya juga meningkat. Jadi dapat disimpulkan bahwa pendapatan asli desa, dana desa dan alokasi dana perimbangan desa berpengaruh terhadap belanja desa. Hasil penelitian ini juga sesuai dengan penelitian yang dilakukan oleh Irawan et al., (2018) yang menyatakan bahwa Pendapatan asli desa, dana desa dan alokasi dana perimbangan desa secara bersama-sama berpengaruh signifikan terhadap belanja desa. Sehingga hipotesis keempat yang menyatakan bahwa pendapatan asli desa, dana desa dan alokasi dana perimbangan desa secara bersama-sama berpengaruh terhadap belanja desa dapat dibuktikan kebenarannya. 


\section{Kesimpulan}

Berdasarkan hasil penelitian dan pembahasan mengenai Pengaruh Pendapatan Asli Desa, Dana Desa, dan Aloksi Dana Perimbangan Desa terhadap Belanja Desa di Desa-desa Kabupaten Sidoarjo Provinsi Jawa Timur tahun 2017-2019, maka pada akhir dari penelitian ini penulis menarik kesimpulan pada Desa-desa di Kabupaten Sidoarjo yang diketahui bahwa Pendapatan Asli Desa berpengaruh positif signifikan terhadap Belanja Desa, kemudian Dana Desa berpengaruh positif signifikan terhadap Belanja Desa, Alokasi Dana Perimbangan Desa berpengaruh positif signifikan Belanja desa, serta Pendapatan Asli Desa, Dana Desa dan Alokasi Dana Perimbangan Desa secara bersama-sama berpengaruh positif dan signifikan terhadap Belanja desa.

\section{Daftar Pustaka}

Darwanto, \& Yustikasari, Y. (2007). Pengaruh Pertumbuhan Ekonomi, Pendapatan Asli Daerah, dan Dana Alokasi Umum Terhadap Pengalokasian Anggaran Belanja Modal. Simposium Nasional Akuntansi X Makassar, 1-5.

Dasuki, T. M. S. (2020). Pengaruh Pendapatan Asli Desa dan Alokasi Dana Desa Terhadap Belanja Desa di Kab. Majalengka. Jurnal Akuntansi Keuangan dan Sistem Informasi, $1(2), 41-54$.

Irawan, M. A. S., Rahayu, S., \& Aminah, W. (2018). Pengaruh Pendapatan Asli Desa, Dana Desa, dan Alokasi Dana Perimbangan Desa Terhadap Belanja Desa (Studi Kasus Pada Desa di Kabupaten Bandung Tahun 2017). Jurnal Aksara Public, 2(4), 190-202.

Mulyani, H. S. (2020). Analisis Fenomena Fly Paper Effect Dalam Belanja Desa Berdasarkan Pendapatan Asli Desa, Dana Desa dan Alokasi Dana Desa. Jurnal Akuntansi Keuangan dan Sistem Informasi, 1(1), 28-46.

Peraturan Menteri Dalam Negeri Republik Indonesia Nomor 113 Tahun 2014. Pengelolaan Keuangan Desa. 31 Desember 2014. Berita Negara Republik Indonesia Tahun 2014 Nomor 2093. Jakarta.

Peraturan Menteri Dalam Negeri Republik Indonesia Nomor 19 Tahun 2020. Pengukuran Indeks Pengelolaan Keuangan Daerah. 24 Maret 2020. Berita Negara Republik Indonesia Tahun 2020 Nomor 284. Jakarta.

Peraturan Menteri Desa, Pembangunan Daerah Tertinggal dan Transmigrasi Republik Indonesia Nomor 5 Tahun 2015. Penetapan Prioritas Penggunaan Dana Desa Tahun 2015. 18 Februari 2015. Berita Negara Republik Indonesia Tahun 2015 Nomor 297. Jakarta.

Peraturan Pemerintah Republik Indonesia Nomor 22 Tahun 2015. Perubahan atas Peraturan Pemerintah Nomor 60 Tahun 2014 Tentang Dana Desa yang bersumber dari Anggaran Pendapatan dan Belanja Negara. 29 April 2015. Lembaran Negara Republik Indonesia Tahun 2015 Nomor 88. Jakarta.

Rokhmawan, D. A. (2018). Analisis Pengaruh Pendapatan Asli Desa (PADesa), Dana Desa (DD), Alokasi Dana Desa (ADD), dan Bagi Hasil Pajak dan Retribusi Terhadap Belanja Desa Bidang Pertanian Tahun 2017 (Studi Empiris Di Seluruh Desa Se-Kabupaten Sragen). Skripsi [Program Studi Akuntansi, Fakultas Ekonomi dan Bisnis, Universitas Muhammadiyah Surakarta]. Diakses melalui http://eprints.ums.ac.id/68245/

Sulistiyoningtyas, L. (2017). Pengaruh Alokasi Dana Desa dan Pendapatan Asli Desa terhadap Belanja Desa di Kecamatan Baron. Simki-Economic, 1(3), 1-15.

Undang-Undang Republik Indonesia Nomor 25 tahun 1999. Perimbangan Keuangan Antara Pemerintah Pusat dan Daerah. 19 Mei 1999. Lembaran Negara Republik Indonesia Tahun 1999 Nomor 72. Jakarta.

Undang-Undang Republik Indonesia Nomor 33 Tahun 2004. Perimbangan Keuangan Antara 
Pemerintah Pusat dan Pemerintahan Daerah. 15 Oktober 2004. Lembaran Negara Republik Indonesia Tahun 2004 Nomor 126. Jakarta.

Undang-Undang Republik Indonesia Nomor 6 Tahun 2014. Desa. 15 Januari 2014. Lembaran Negara Republik Indonesia Tahun 2014 Nomor 7. Jakarta. 